\title{
A framework for valuing the human dimensions of engineered systems
}

\author{
Jonathan D Simm ${ }^{1}$ \\ ${ }^{1}$ HR Wallingford and Visiting Researcher University of Nottingham, Howbery Park, Wallingford, Oxfordshire OX10 8BA, UK \\ (Email: j.simm@hrwallingford.co.uk)
}

Published in the Engineering Sustainability, Volume 165 Issue ES3 (2012)

\section{Abstract}

As well as safely delivering their basic functions, ethical considerations suggest that sustainably engineered systems should wherever possible offer related amenity and aesthetic value and be socially connected to the communities they serve. Given the evident gap in assessment tools in this area, semi-structured interviews and case study work have been conducted with engineering practitioners in the field of flood and coastal risk management and with community members and activists, to identify a way in which these human dimensions of existing engineered structures and systems might be assessed and scored/ranked in a manner consistent with their technical assessment. The approach is founded on a trinitarian framework of Order/Security, Belonging/Justice and Imagination/Inspiration which reflects both Vitruvius' original architectural principles (strength, utility and beauty) and insights drawn from key thinkers from a wide range of disciplines. Ideas and concerns about the practical assessment and delivery of human dimensions within the framework are discussed.

\section{Keywords}

Social impact; buildings, structures; design; floods; floodworks

\section{Introduction - social performance of structures and systems in civil engineering}

Use of systems-based approaches (Hall et al, 2003; Hall et al, 2006; Gouldby et al, 2008) for analysing and managing stocks of engineering infrastructure assets has drawn attention to the need for an improved understanding of engineering performance and the reliability of engineered components, such as flood defences (Simm et al, 2006; Simm et al, 2008), and the need to understand their strengths and weaknesses as part of an overall system. The characterisation of the performance of engineering assets is often supported by some form of simple scoring system (Hooper et al, 2009, 73-76) to grade the structural condition of their assets, such as the five point visual inspection scale (Table 1) used by the Environment Agency (Flikweert \& Simm, 2008). Such scales are used to capture deterioration in asset condition and improvements delivered by management action.

This approach to asset management has, perhaps rightly, focussed largely on the engineering functionality of the assets and asset systems, with little attention given to date to other aspects. However, as the science 
associated with managing asset systems matures, there is also scope to consider, as in this paper, the social functioning or human dimensions of such systems.

Professional responsibility of civil engineers for the human dimensions of engineered systems has been well understood for many years, being enshrined in the very concept of civil engineering itself, whether taken as the original Thomas Tredgold definition in the ICE Royal Charter of 1828 as

\section{'the art of directing the great sources of power in nature for the use and convenience of man ...'}

or the more modern definition recently adopted by ICE Council (Oliver, 2007):

'Civil engineering is a vital art, working with the great sources of power in nature for the wealth and wellbeing of the whole of society."

The idea of extending the scope of civil engineering beyond "the use and convenience of man" to "the wealth and well-being of the whole of society" is in fact already embedded within recent codes of professional conduct. ICE $\left(2004,3^{\text {rd }}\right.$ rule) requires 'all members [to] have full regard for the public interest, particularly in relation to matters of health and safety, and in relation to the well-being of future generations.' Similarly the American Society of Civil Engineers (2009, $1^{\text {st }}$ cannon) requires 'engineers [to] hold paramount the safety, health and welfare of the public and [to] strive to comply with the principles of sustainable development in the performance of their professional duties.' Embedded concepts such as 'the public interest', 'well-being' and 'sustainability' extend the narrow harm-avoidance remit of health and safety legislation and practice to the seeking of the positive and sustainable good of the citizens of the world and have led to the triple bottom line (people-planet-profit) aims of sustainable development (Parkin et al, 2003) and to the emergence in the business world of corporate social responsibility.

\begin{tabular}{|l|l|l|}
\hline 1 & Rating & $\begin{array}{l}\text { Description } \\
\text { Cosmetic defects that will have no effect on } \\
\text { performance }\end{array}$ \\
\hline 2 & Good & $\begin{array}{l}\text { Minor defects that will not reduce the overall } \\
\text { performance of the asset }\end{array}$ \\
\hline 3 & Fair & $\begin{array}{l}\text { Defects that could reduce performance of the } \\
\text { asset }\end{array}$ \\
\hline 4 & Poor & $\begin{array}{l}\text { Defects that would significantly reduce the } \\
\text { performance of the asset. Further investigation } \\
\text { needed. }\end{array}$ \\
\hline 5 & Very Poor & $\begin{array}{l}\text { Severe defects resulting in complete } \\
\text { performance failure }\end{array}$ \\
\hline
\end{tabular}

Table 1: Environment Agency asset condition grade scale

However, as Parkin et al (2003) identify, in practice there is considerable vagueness in the understanding of the practical significance of these ideas when applied to infrastructure, especially with natural system management with its interactions (Fig. 1) with environmental and social issues, despite tools being available to manage our understanding of such interconnected systems (Blockley \& Godfrey, 2000; Checkland \& Poulter, 2006). 
This paper attempts to start to fill this gap in practical understanding by setting out an approach to the assessment of the human dimensions of (largely existing) infrastructure systems and their components and to do this in a manner that is compatible with the existing scoring systems used for the assessment of engineering performance.

The approach is to draw first on a number of theoretical understandings to identify a series of common human dimensions. The paper then explains the qualitative methodology, mainly based on interviews, used to gather data in the example field of flood risk management. The coded data from these interviews combined with the theoretical understandings suggest a simple overall structure for human dimensions within which more detail can be inserted depending on the type of engineering structure or system and the opinions of professionals and citizens involved at a local level. Finally, the paper examines future methods of assessment within the framework and possible obstacles to the future inclusion of human dimensions within engineering structures and systems.

\section{Existing approaches to understanding human dimensions and their relation to engineered structures and systems}

If the social performance and reliability of engineered systems is important for public interest, well-being and sustainability, how then should these human dimensions be assessed? This requires consideration of how human needs might be assessed in a general sense and then how the built environment created by engineered structures and systems might contribute towards meeting these needs. This section examines approaches to these questions by authors that have considered them from a range of different disciplines and then seeks to synthesise the emergent ideas.

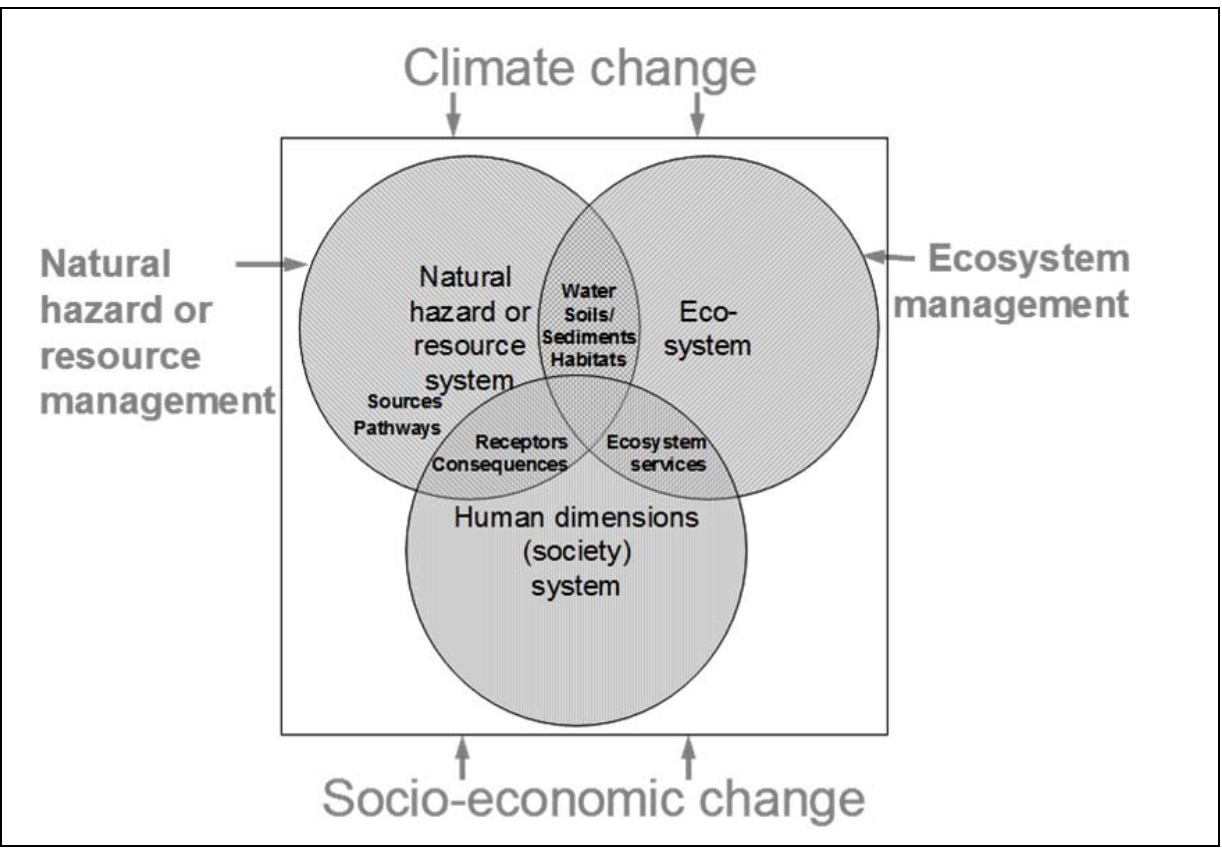

Fig. 1 Human dimensions in natural hazard or resource management 
1. way of life - that is, how people live, work, play and interact with one another on a day-to-day basis;

2. culture - that is, people's shared beliefs, customs, values and language or dialect;

3. community - its cohesion, stability, character, services and facilities;

4. political systems - the extent to which people are able to participate in decisions that affect their lives, the level of democratisation that is taking place, and the resources provided for this purpose;

5. health and wellbeing - health is a state of complete physical, mental, social and spiritual wellbeing and not merely the absence of disease or infirmity;

6. personal and property rights - particularly whether people are economically affected, or experience personal disadvantage which may include a violation of their civil liberties;

7. fears and aspirations - people's perceptions about their safety, their fears about the future of their community, and their aspirations for their future and the future of their children; plus

8. the eco-system services provided by their environment - the quality of the air and water people use; the availability and quality of the food they eat; the level of hazard or risk, dust and noise they are exposed to; the adequacy of sanitation, their physical safety, and their access to and control over resources.

Fig. 2. International Association of Impact Assessment (IAIA) categories of human impacts

\subsection{Human needs}

One approach to assessing human needs which is close to current engineering practice is to view the human dimensions of engineered systems in terms of impacts (positive or negative). An impact can be described as "the change in a ... parameter over a specified period and within a defined area, resulting from a particular activity compared with the situation which would have occurred had the activity not been initiated" (Wathern, 1988, 7). Within this general description, social impacts can be defined as "the intended and unintended consequences on the human environment of planned interventions (policies programs, plans, projects) and any social change processes invoked by those interventions" (Vanclay, 2002, 190). Lists and categories of social impacts have been developed by various authors, a recent authoritative list having been outlined (Fig. 2) by the International Association of Impact Assessment (2003). This approach has proved attractive in the field of flood risk management, the IAIA list of social impacts being adopted in the Appraisal Summary Table approach (Environment Agency, 2010) recommended for assessment of engineering scheme options. 
1. Life - ability to live a life of normal length and at least minimum quality.

2. Bodily Health, including reproductive health, adequate nourishment and shelter.

3. Bodily Integrity, including freedom of movement; security against violent assault; sexual satisfaction and choice.

4. Senses, Imagination, and Thought, including ability to imagine, think, reason, be creative and experience pleasure - supported by an adequate education, protected by guarantees of freedom of expression and being able to avoid non-beneficial pain.

5. Emotions, including being able to love, grieve, and experience longing, gratitude, and justified anger without one's emotional development being blighted by fear and anxiety.

6. Practical Reason, including being able to form a conception of the good and to engage in critical reflection about the planning of one's life, protected by liberty of conscience and religious observance.

7. Affiliation.

- Being able to engage in various forms of social interaction protected by freedom of assembly and political speech.

- Being able to be treated as a dignified being having self-respect and not being discriminated against on the basis of race, sex, sexual orientation, ethnicity, caste, religion, national origin and species.

8. Other Species. Being able to live with concern for and in relation to animals, plants, and the world of nature.

9. Play. Being able to laugh, to play, to enjoy recreational activities.

10. Control over one's Environment.

- Political. Being able to participate effectively in political choices that govern one's life;

- Material. Being able, on an equal basis with others, to hold property, to seek employment and to be free from unwarranted search and seizure.

Fig. 3. Martha Nussbaum's $(2000,2006)$ Central Human Capabilities summarised

There is, however, a difficulty with the concept of an impact because it addresses the change in a human dimension (brought about by an intervention) rather than the total value of that dimension relevant to the discussion in this paper. The categories of impacts in Fig. 2 remain helpful, nonetheless, and can be compared with other lists of human dimensions that have been drawn up authors with an interest in the metrics of social justice. The theory of justice set out by John Rawls (1971) has been influential in this area, as it introduced the concept of social primary goods - "people's holdings of or prospects of holding external goods" (Robeyns \& Brighouse, 2010, 2). Examples of these (Rawls, 2001, 58-61) include: basic liberties (freedom of thought and liberty of conscience, etc), freedom of movement and free choice of occupation, powers and prerogatives of offices of responsibility, income and wealth and a social basis for self-respect. Amartya Sen (1985) argued that, rather than thinking about people's holdings of primary goods given that human needs vary considerably with factors such as health, age, climatic conditions, location and temperament, the equality principle of distributive justice amongst citizens (Miller, 1999) is better served by focusing on capabilities. Capabilities are the various combinations of functionings that a person can achieve 
(Sen, 1993, 40) and this concept has been extended by Martha Nussbaum (2000; 2006), into a list of central human capabilities (Fig. 3) which have been very influential internationally, assisting the UNDP in defining a Human Development Index.

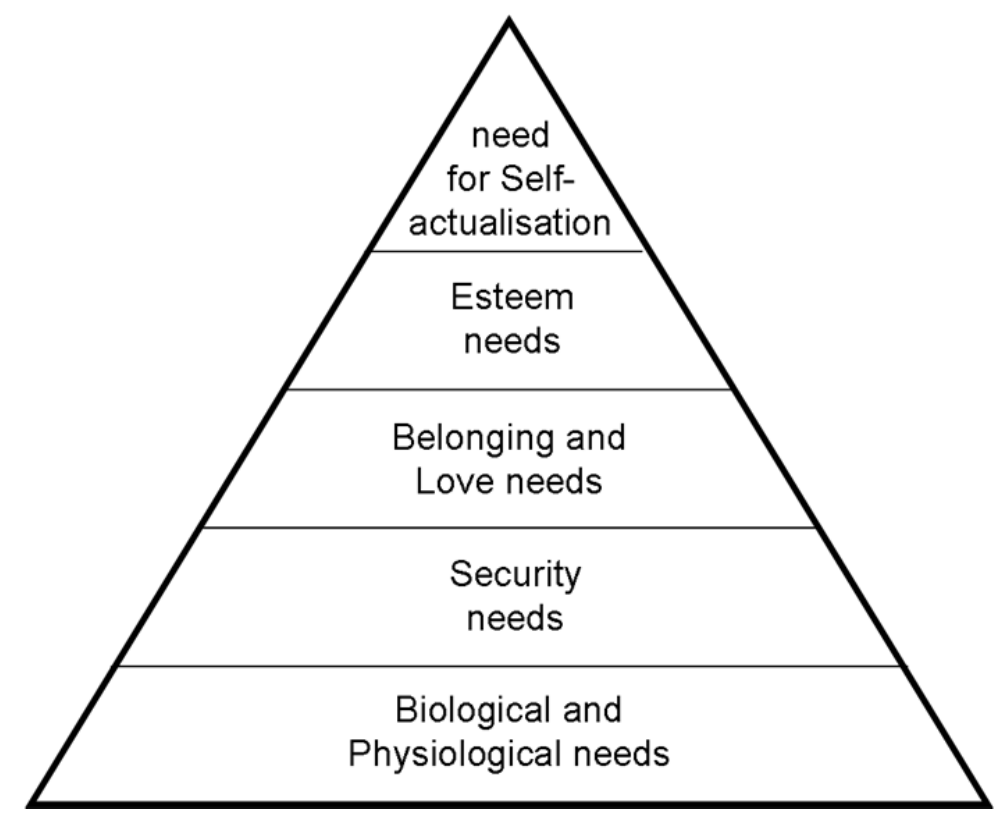

Fig. 4 Maslow's hierarchy of needs. Lower parts of the hierarchy must be satisfied before higher parts

Despite the evident usefulness of these lists, the fundamental structuring of the importance or priority of various human dimensions in relation to each other is not given much attention. This may imply an assumption that, in each individual case, scaling factors will be developed by some form of consensual process to weight the scores of the various human dimensions (Bisset, 1988, 49). However, one possible theoretical starting point for such structuring is that offered by psychologist Abraham Maslow $(1943,1954)$. Maslow proposed a hierarchy of human needs (Fig. 4). His idea was that basic human needs had to be met before 'higher' needs such as personality growth could be met. Whilst his ideas have been extensively challenged over the years in terms of the restricted case study methodology used to derive them, whether satisfying lower needs helps the higher needs to emerge and the details of what he meant by selfactualisation, his idea remains intuitively accurate that "we do have a difficult time reaching the heights of experience if we are preoccupied with attaining the base essentials of life" (Neher, 1991, 109). In any event, despite these caveats, the elements of the hierarchy remain potentially useful.

\subsection{Human dimensions of engineered structures and systems}

The classical starting point for thinking about these issues in regard to buildings and architecture is the architectural principles of Vitruvius: firmitas, utilitas, and venustas. These are often remembered in the words of Sir Henry Wotton's (1568 - 1639) translation as "firmness, commodity and delight", or in more modern language as strength, utility, and beauty (Gwilt, 2007). Gwilt (2007) translates Vitruvius thus: 


\begin{abstract}
"Strength arises from carrying down the foundations to a good solid bottom, and from making a proper choice of materials without parsimony. Utility arises from a judicious distribution of the parts, so that their purposes be duly answered, and that each have its proper situation. Beauty is produced by the pleasing appearance and good taste of the whole, and by the dimensions of all the parts being duly proportioned to each other."
\end{abstract}

And although Western architects have challenged Vitruvius' threefold characterization, particularly during the period 1910 to 1960, there has been a renewed recognition since about 1965 that "there can be an independent quality of delight in architecture and that the most esteemed architecture endeavours to produce the greatest pleasure for the price, with function and durability being satisfied as well" (Roth, 2007, $67)$.

But is Vitruvius' threefold characterisation relevant for engineered systems and structures (i.e. infrastructure) in the way that it is for buildings? Major bridges certainly attract significant architectural attention. But even in much less high-profile engineering, the issues of utility and delight can have a significant role to play. As an example, Cruickshank et al (2005), in an examination of the development of the sea defences associated with a new high quality coastal housing scheme, discuss the interplay between the engineering (firmitas) aims on which a coastal engineer might typically focus and the architectural (utilitas and venustas) requirements on which the architect focuses (Table 2).

The question of ranking of the human dimensions is also relevant when considering engineered systems and structures, since infrastructure has a significant role to play in ensuring security of supply of the more basic needs, such as food, water, shelter and clothing. It is difficult to see how engineered systems and systems can be evaluated by a civil engineer as delivering value in terms of commodity and delight unless they have first been arranged or ordered to deliver their basic firmitas or 'security' function. (This is notwithstanding the fact that to achieve the desirable goal of meeting 'higher needs' might in some situations be in conflict with the provision of firmitas.) Following political scientist Wolfers $(1952,485)$ who called it 'the absence of threats to acquired values', but recognising that it is never absolute, this paper characterises 'security' as the degree of absence of threats to acquired values. (cf Baldwin, 1997, 13)

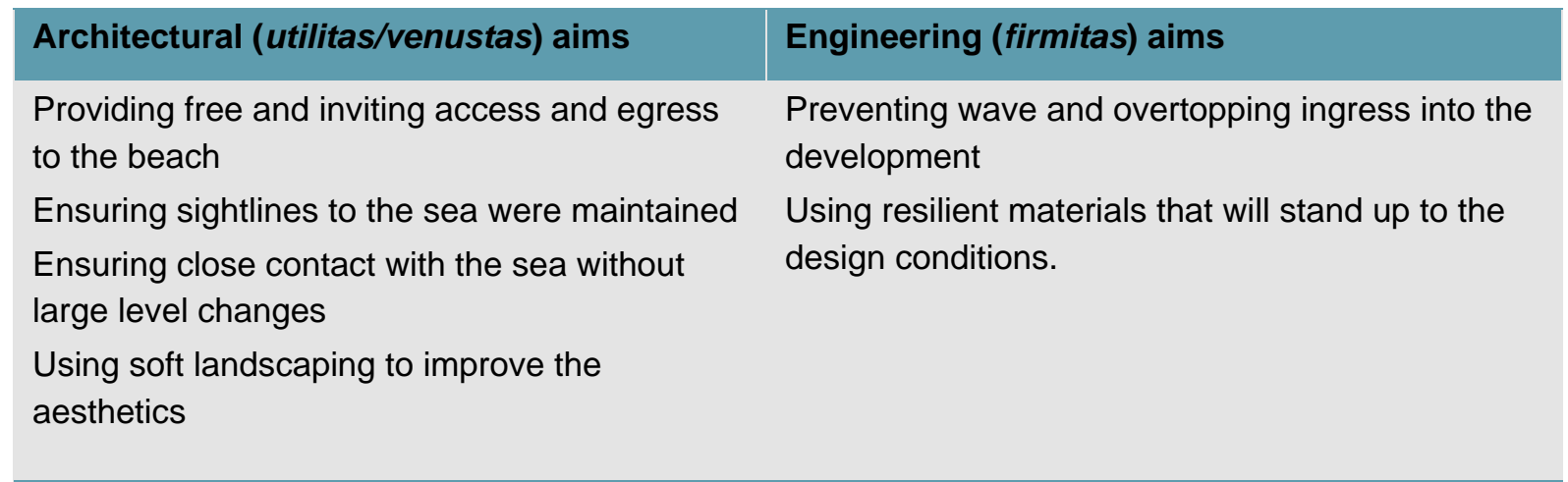

Table 2. Example requirements for waterfront developments (after Cruickshank et al, 2005) 


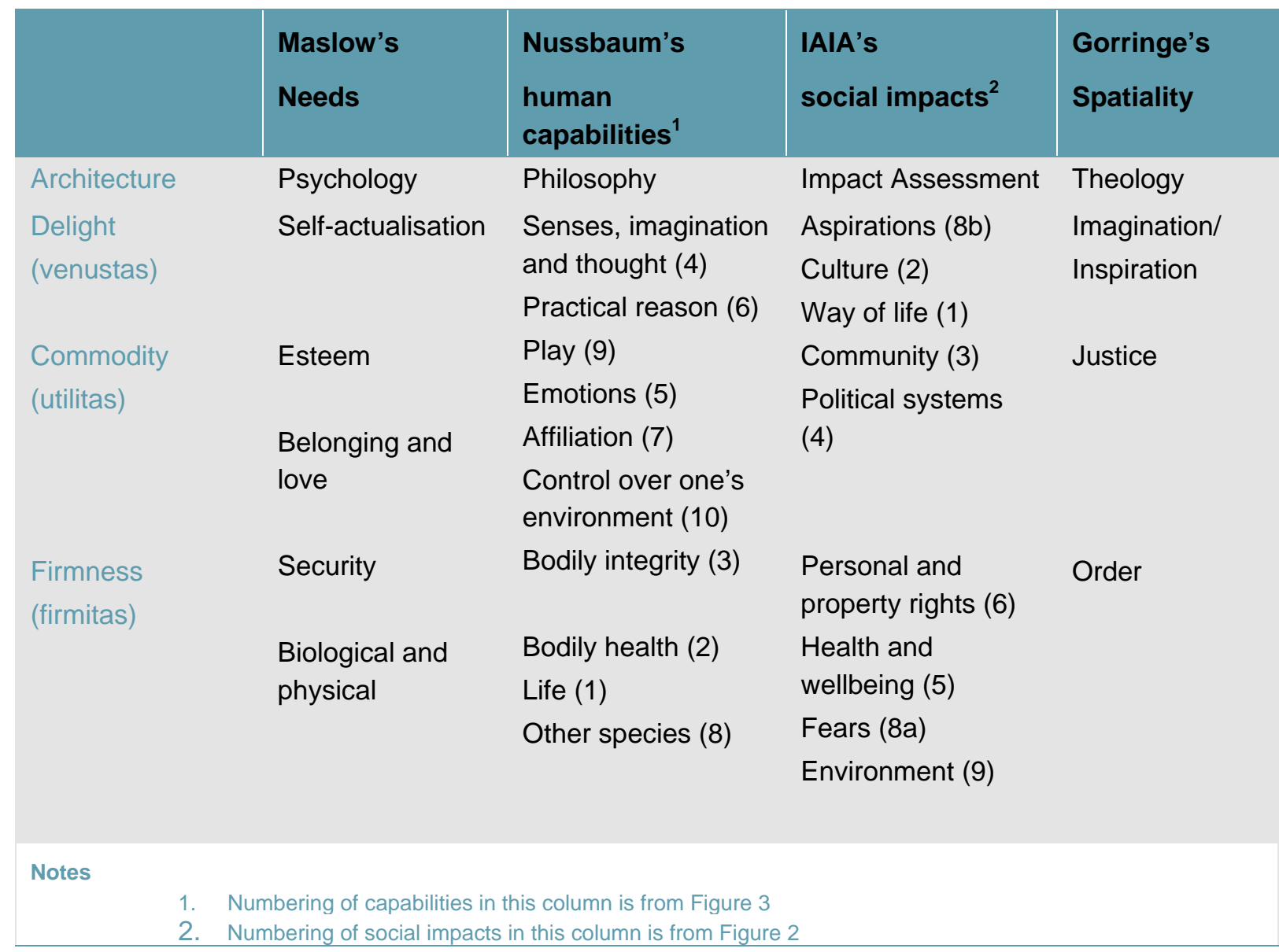

Table 3. Social criteria from different authors/disciplines loosely matched

\subsection{Linking human needs and engineering}

Making links between Vitruvius' characterisation and the previously discussed frameworks is not straightforward, but some significant parallels can be drawn out if the exercise is attempted. Table 3 shows a loose mapping or comparison of the dimensions identified by the various authors discussed above. These are placed in the columns and reordered so that there is a measure of horizontal equivalence to facilitate the identification of any commonalities or grouping categories. Although there are few exact matches, at the bottom of the table, Vitruvius' 'firmness' is seen to map readily onto Maslow's basic needs and human security and to Nussbaum's first three capabilities. At the top of Table 3 there are also strong connections between the principle of delight, Maslow's self actualisation and the comparable items in the Nussbaum and IAIA schedules. In the centre of the mapping it is harder to see exact parallels and this may be because Vitruvius' principle of utility may not be the fundamental concept when considering human needs for belonging, love and esteem.

As a further input, the final column of Table 3 includes the simple spatiality outlined by Timothy Gorringe in his 'Theology of the built environment' (Gorringe, 2002). Here he brings together human needs and engineering and argues (Gorringe, 2002, p49) for a "Trinitarian mapping of spatiality", using keywords of Imagination, Order and Justice. Evaluating his 'mapping', it seems to both embrace and resonate with the various insights described above, although without ordering the ideas and thus avoiding Maslow's assertion of the existence of a hierarchy. 
Firstly, the idea of Order ('God the Creator ... brings order out of chaos') captures both the Vitruvian principle of strength (firmitas) but also the human needs of security of life, health and property. The concept of order can operate at a range of scales and embraces issues of spatial hierarchies/interrelationships seen to be important by writers as diverse in discipline as architects (Alexander, 2004), built environment professionals (Bartuska, 2007) and philosophers (Inwood, 1997). Whilst the production and maintenance of social order may historically have been the central question in the social sciences (Cook et al, 2005, 1), this paper restricts the concept of order to a combination of Vitruvian physical firmitas and human security (as defined above).

Secondly, the idea of Imagination or Inspiration ('God the Holy Spirit ... is the inspirer of ... visions of a better human environment') is roughly equivalent to the Vitruvian principle of delight (venustas) and the higher cultural/aspirational human needs described by Maslow as self-actualisation. It also embraces the way that sympathetic engineering in a natural environment has inspired artists, poets and writers.

Finally, loosely corresponding to Maslow's middle ground, the idea of [social] Justice ('God the Reconciler takes flesh in order to teach peace to the nations') begins to provide the missing concept to embrace both the utility of Vitruvius and the belonging, love and esteem needs identified by Maslow and the other writers. The built environment should be the place 'where social justice is, quite literally, made concrete' (op cit, p. 49) so that people feel they belong and are not alienated. Difference and conflict cannot be avoided, but they should be harnessed creatively in humility and hope.

\begin{tabular}{|l|l|}
\hline++ & $\begin{array}{l}\text { Social justice } \\
\text { Action increases the capacity to deliver improved standards of social justice } \\
\text { (fairness in distribution of benefits and costs, and in engagement), promptly, } \\
\text { and with associated progressive re-evaluation. }\end{array}$ \\
\hline+ & $\begin{array}{l}\text { The action provides some capacity to deliver improved standards of social } \\
\text { justice. }\end{array}$ \\
\hline 0 & No deterioration of social justice \\
\hline- & The action reduces capacity to deliver minimum standards of social justice. \\
\hline- & $\begin{array}{l}\text { Action strongly reduces capacity to deliver minimum standards of social } \\
\text { justice, causes measures of social justice to worsen }\end{array}$ \\
\hline
\end{tabular}

Table 4. Scoring system for social justice used in the Foresight Future Flooding project

Bringing Gorringe's ideas together with those discussed above, the author has created a framework making use of the symbol of the Celtic Cross (Fig. 5) which symbolises a holistic view of life (Silf, 2001; Bryce, 1995). The vertical axis-mundi represents Order and Security being achieved, simultaneously respecting general principles of engineering design in delivering environmentally sympathetic form and function but mediating these into local solutions with due respect for the security needs of local communities. The wheel or circle, which traditionally indicates glory or spirituality, here represents the Inspiration or Imagination dimension, reflecting the aesthetic and the element of delight and fulfilment associated with engineering assets. Finally, the horizontal axis represents the tension of the aspect of social Justice which seeks to brings reconciliation and connection - a sense of 'Belonging' - to place-based communities through inclusive forms of infrastructure, avoiding a sense of exclusion or alienation. 


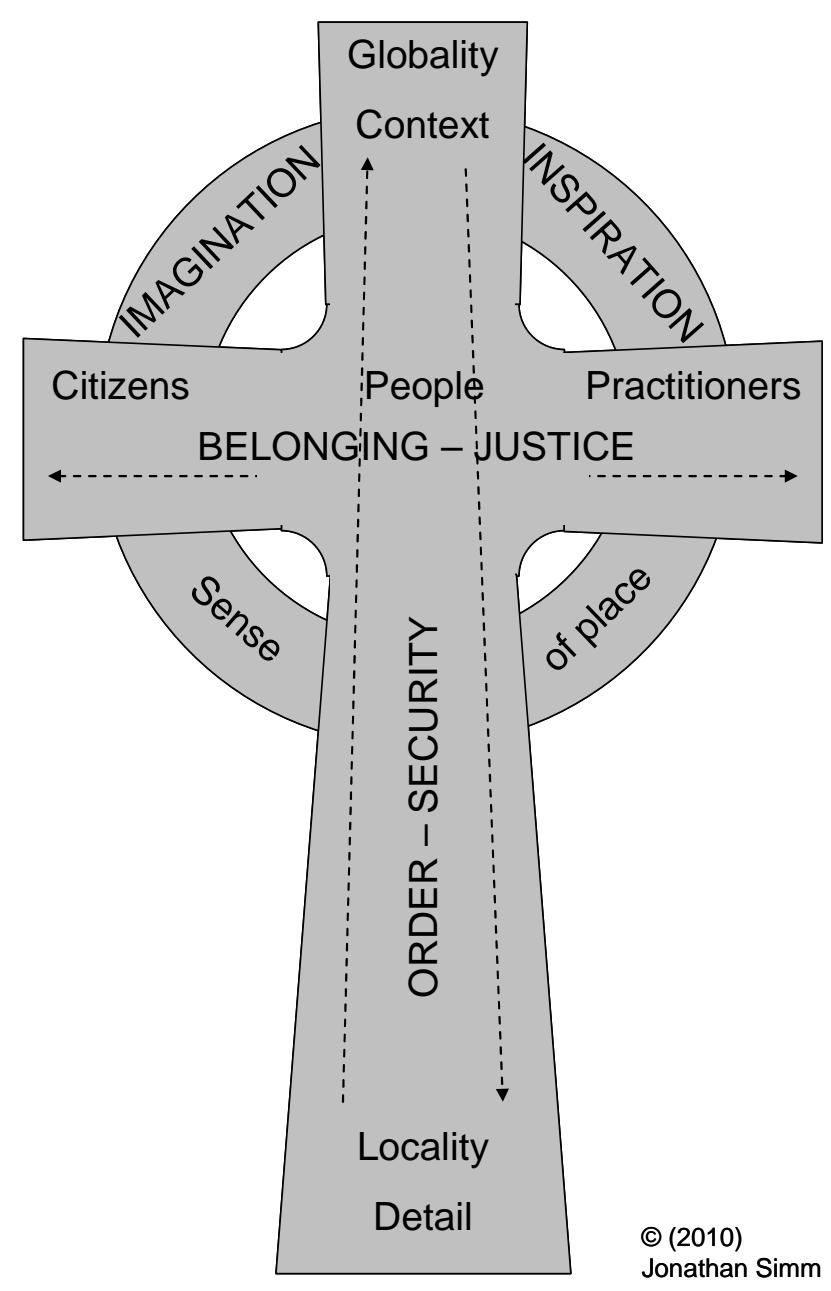

Fig. 5. Model of social features of FCERM assets

With regard to the horizontal Belonging-Justice dimension, it may not be immediately easy to see how the need for belongingness is related to engineering structures. Ever since Frederick Tönnies wrote in 1877 of the industrial revolution move from Gemeinschaft (historic community of the village, based on mutual aid and trust, and centred on family, neighbourhood and friendship) to that of Gesellschaft (the association of the anonymous city, based on individual self-interest and contract), the concept of 'community' and its link to 'place' has been essentially contested (Cohen, 1985; Delanty, 2003). However many writers, like geographer Diane Warburton $(1998,17)$, now argue that whilst the concept of 'community' may be seen to be mainly to do with relationships between people, it is also to do with relationships between people and the place in which they are located. Ruth Liepins $(2000,27)$, commenting on the work of social theorists Harvey and Massey, notes that

\footnotetext{
“"community' and 'place' are two concepts that are constantly intertwined in highly complicated ways. Communities may not be primarily identified according to their coincidence with particular places ... Nevertheless, communities involve social relations that occur transiently or continually in both places and spaces."
} 
Psychologists McMillan \& Chavis $(1986,15)$, in their classic research on the concept of the "psychological sense of community" first postulated by Seymour Sarason (1974), found that included amongst the various components which were important to people in helping them to 'belong' to a community (such as emotional safety and sense of identification) were the boundaries and common symbol system associated with physical features, the physical and intangible features tending to interact with one another in a self-reinforcing way.

Thus there is a persuasive case that a 'community' of people is to some degree linked to the 'place' in which it exists and thus to the engineering systems (e.g. the sea defences of a coastal town) which form part of that place, particularly, as identified by architectural and built environment writers, such as Alexander et al (1978), if these provide features that are readily useable by the public, such as:
a) pedestrian walkways and road crossings
b) cycle paths
c) facilities for children; adventure places
d) facilities for the old and disabled
e) arrangements to allow people to safely use (parts of) the area at night
f) public 'outdoor rooms'
g) provision for animals and pets
h) places to sit and to sleep
i) walls suitable for sitting on.
j) places for summer awnings to provide shade etc.

It is the availability (with freedom to use) and suitability of such features which allow people to feel that they belong in a place and indeed that the engineered system belongs to them (Fig. 6) and this goes well beyond provision of minimum requirements such as those for access in the Disabilities Discrimination Act (1995).

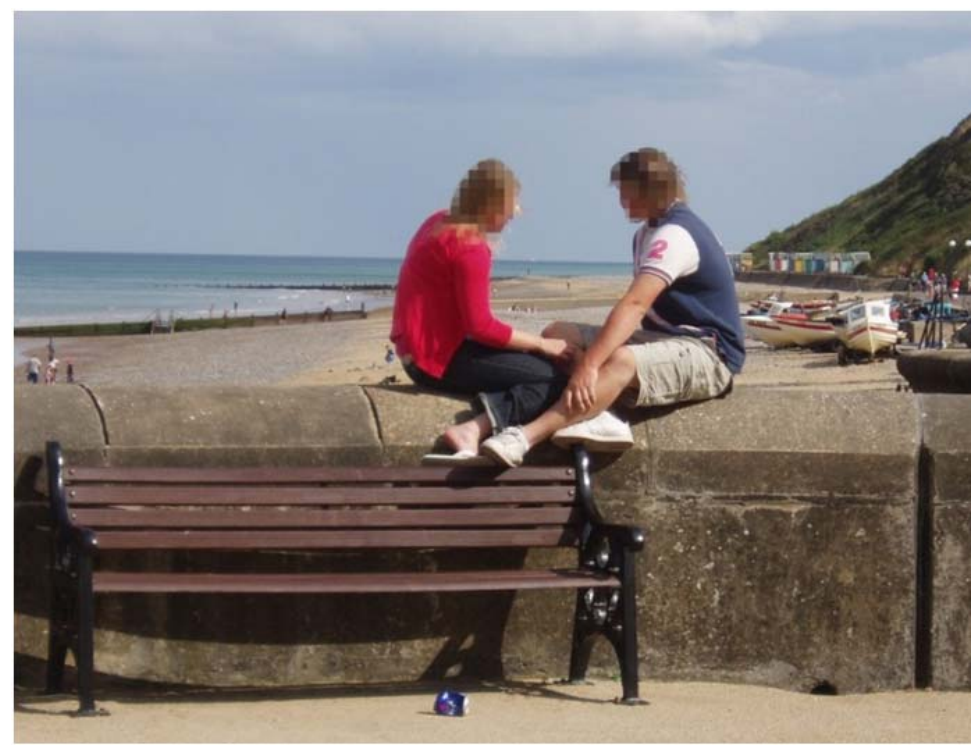

Fig. 6. Couple 'owning' sea wall at Cromer, UK (photo J. Simm)

Whether or not the symbol in Fig. 5 is attractive, it is argued that the dimensional groupings of order-security, belonging-justice and imagination-inspiration have a broad pedigree in the literature which makes them persuasive. They are also supported, as the following sections will make clear, by the interviews and case studies conducted by the author. 


\section{Methodology: case study in flood risk management infrastructure}

The example of flood risk management infrastructure was used to investigate the approach set out in the previous section. Flood risk is most commonly (Gouldby \& Samuels, 2005; Hall et al, 2003) expressed in economic terms and is characterised as the combination of the probability of flooding with its consequences. Although there is an emerging move (Tunstall et al, 2010) towards a portfolio of approaches to managing flood risk that includes such non-structural measures as source control, land-use management and emergency planning, a significant role has been retained for flood defences and other engineering measures (Office of Science \& Technology, 2004) in blocking or controlling pathways of flood water from sources to receptors and thus in reducing the probability of flooding. It is the human dimensions of these physical assets on which the case-study focused.

The approach adopted is generally described as ethnographic research. This can involve a wide variety of techniques (Cook \& Crang, 1995), but the main one adopted for this research was that of semi-structured, one-to-one interviews. These were held with 41 individuals, 20 of whom were flood risk management professionals. The remainder were leaders and citizen members of community self-help groups or volunteering charities involved in the management and maintenance of river channels and flood defences plus two artists who were discovered to be deeply interested in these issues. Unlike research involving questionnaires, the aim in recruiting interviewees was "not to choose a representative sample, rather to select an illustrative one" (Valentine, 2005, 112). In practice, there were a limited number of relevant individuals to call on around England. Professionals were identified from various national and local government departments and agencies and the citizen representatives were identified from the limited number of self-help groups existing in this area. For a measure of contrast, three of the respondents were from the USA, selected on an opportunistic basis during a professional visit. The interviews followed wellestablished practice guidance for such qualitative interviewing (Burgess, 1982; Fielding \& Thomas, 2001; Valentine, 2005; Longhurst, 2003), making use of a previously compiled checklist of points to be raised and questions to be answered. Although a separate focus of the research was on the role of self-help groups, all interviews contained questions relevant to the theme of this paper. The interviews were subsequently recorded and transcribed in their entirety for subsequent coding and analysis of emergent themes. As each new interview was analysed and coded, comparisons and contrasts were made and thematically similar segments of text identified from which ideas were built, theories developed or confirmed and formal relationships and structures established (Crang, 2005; Cook \& Crang, 1995, 76-92).

Perhaps slightly unexpectedly, it was difficult to get citizen members of self-help groups to talk about human dimensions beyond delivering the security of measures to mitigate flooding and coastal erosion (although this in itself was an interesting outcome). Professionals, on the other hand, seemed to be more willing to draw on their personal experience to indicate wider human aspects. The citizen interviews were therefore supplemented by ethnographic observations during various site visits. In particular visits were arranged to two popular sea-side towns (Bournemouth and Cromer). Here a participatory diagramming approach $(\mathrm{H}-$ frame) was used to encourage people as they passed by to indicate what they thought of the seafront. This involved their identifying on sticky paper notes those features they thought were more positive or negative and giving the seafront an overall rating on a scale from 1 to 10 (Kesby et al, 2005). 


\section{Valuation/scoring of human dimensions}

The results of combining the literature, interview and ethnographic evidence are shown in Table 4, which maintains the three main categories of human dimensions of engineering systems discussed above: ordersecurity; belonging - justice; imagination - inspiration. This table contains three components.

a) Generalised descriptions suitable for condition grading an engineering structure or system on a scale of 1 to 5 .

b) Examples of human dimensions of flood risk management assets within each category. These include aspects which emerged from the participatory diagramming and author observations during the sea-side town visits and embrace a very pervasive appreciation which emerged for cleanliness (security of health) and tidiness (visual inspiration).

c) Illustrative example statements from the interviewees.

Various aspects of this table are discussed below.

\subsection{Use of a simplified scale to assess human dimensions}

As well as the use of a simplified scale in assessing the structural condition of engineering assets mentioned in the introduction to this paper, there is also some pedigree for the use of a simplified scale to score the elements of the sustainability of projects, such as the human dimensions scale given in Table 4. Bell \& Morse (2003), for example, advocate its use to create a RADAR, star or spider diagram to illustrate a number of aspects simultaneously. This was the approach adopted to enable experts to score the sustainability of a number of response measures across a range of socio-economic and climate change scenarios as part of the Foresight Future Flooding project (Simm \& Thorne, 2007). Along with flood risk reduction, the spider diagram (Fig. 7) included dimensions of cost-effectiveness, environmental quality, social justice, precaution and robustness. Each dimension was scored using a descriptive scale, similar to the example for social justice shown in Table 5.

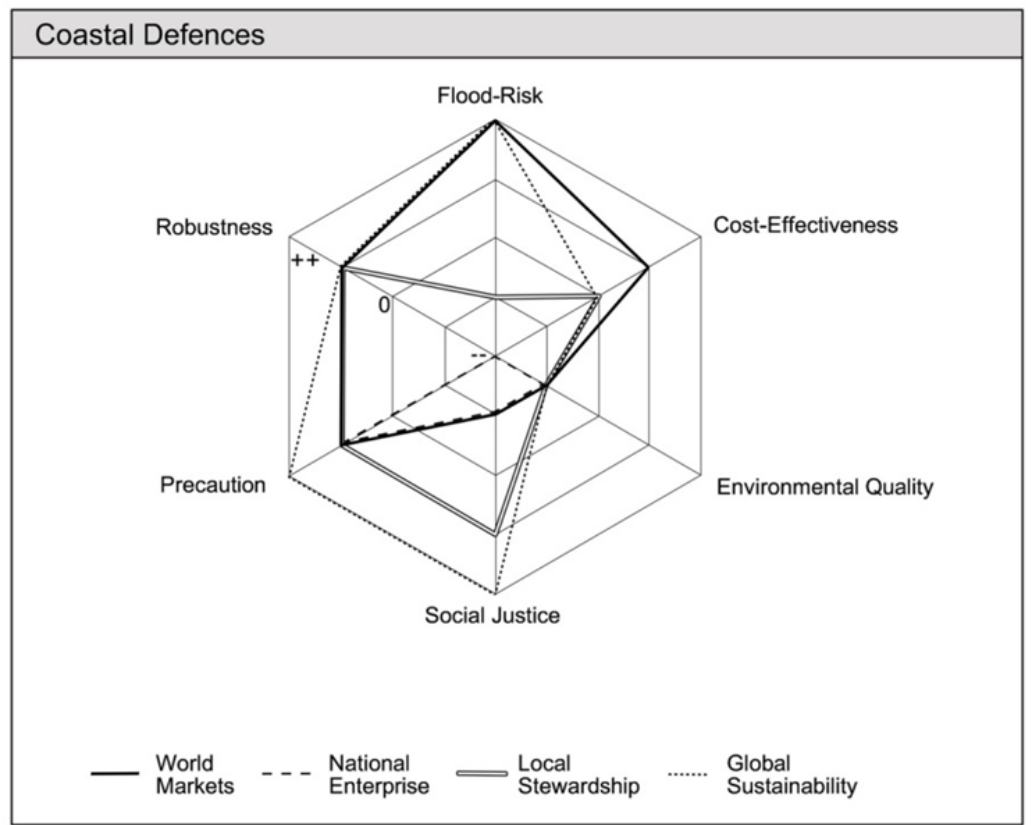

Fig. 7. Example sustainability scoring diagram from Foresight Flood \& Coastal Defence Project (2004) 
Performance feature: INSPIRATION/DELIGHT

\begin{tabular}{|c|c|c|c|}
\hline $\begin{array}{l}\text { Condition } \\
\text { Grade }\end{array}$ & $\begin{array}{l}\text { Generalised } \\
\text { description }\end{array}$ & $\begin{array}{l}\text { Examples of features that could be } \\
\text { assessed (drawn from flood risk } \\
\text { management) }\end{array}$ & $\begin{array}{c}\text { Example statements by author's } \\
\text { interviewees illustrative of } \\
\text { inspiration/delight }\end{array}$ \\
\hline \multirow[t]{2}{*}{ CG1 } & $\begin{array}{l}\text { Inspirational sensory } \\
\text { effect }\end{array}$ & \multirow{10}{*}{ 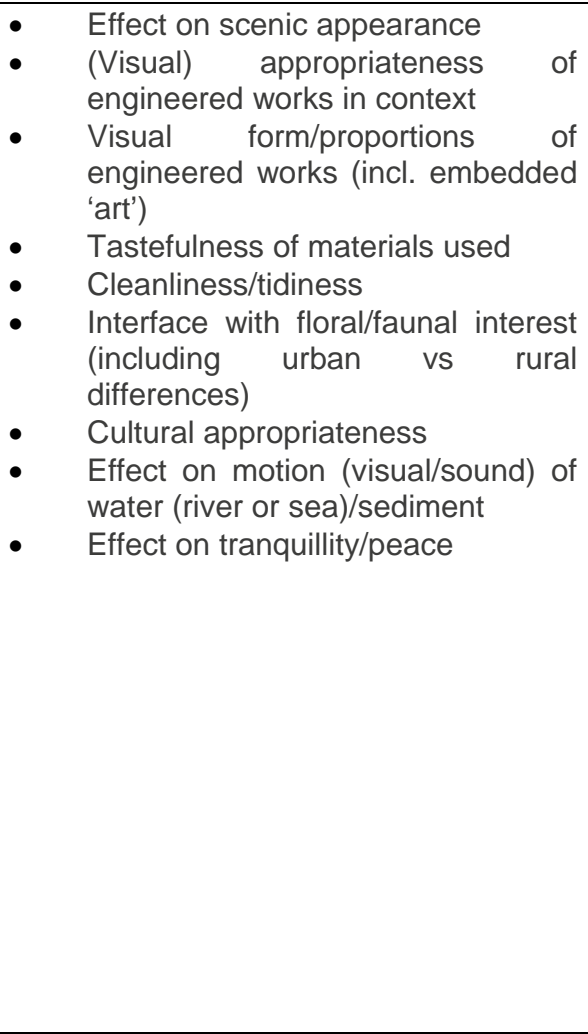 } & $\begin{array}{l}\text { 'Our coast is much photographed, } \\
\text { much painted and much used for }\end{array}$ \\
\hline & $\begin{array}{l}\text { Very enriched sense } \\
\text { of place }\end{array}$ & & $\begin{array}{l}\text { artistic purposes, either the natural } \\
\text { features of the coast or the man- } \\
\text { made features or the human activity }\end{array}$ \\
\hline \multirow[t]{2}{*}{ CG2 } & $\begin{array}{l}\text { Pleasing sensory } \\
\text { effect }\end{array}$ & & $\begin{array}{l}\text { on the coast. It's very, very strong in } \\
\text { people's psyche in the area, and they }\end{array}$ \\
\hline & $\begin{array}{l}\text { Improved sense of } \\
\text { place }\end{array}$ & & $\begin{array}{l}\text { come here specifically to photograph } \\
\text { or paint here. See it, feel it.' } \\
\text { [professional] }\end{array}$ \\
\hline \multirow[t]{2}{*}{ CG3 } & Neutral sensory effect & & '...wherever you get the noise of \\
\hline & $\begin{array}{l}\text { Sense of place } \\
\text { unaffected }\end{array}$ & & $\begin{array}{l}\text { water it's attractive to people, so we } \\
\text { get that babbling brook or whatever. }\end{array}$ \\
\hline \multirow[t]{2}{*}{ CG4 } & $\begin{array}{c}\text { Displeasing sensory } \\
\text { effect }\end{array}$ & & $\begin{array}{l}\text { And I think the same applies to } \\
\text { outfalls." [professional] }\end{array}$ \\
\hline & $\begin{array}{l}\text { Reduced sense of } \\
\text { place }\end{array}$ & & $\begin{array}{l}\text { '... make [the weir] into something } \\
\text { that's more functional and more } \\
\text { aesthetically pleasing, and fitted the }\end{array}$ \\
\hline \multirow[t]{2}{*}{ CG5 } & $\begin{array}{l}\text { Repulsive sensory } \\
\text { effect }\end{array}$ & & $\begin{array}{l}\text { new scheme, but ... give it back that } \\
\text { sense of place.' [professional] }\end{array}$ \\
\hline & $\begin{array}{l}\text { Very impoverished } \\
\text { sense of place }\end{array}$ & & \\
\hline \multicolumn{4}{|c|}{ Performance feature: JUSTICE/BELONGING } \\
\hline $\begin{array}{l}\text { Condition } \\
\text { Grade }\end{array}$ & $\begin{array}{l}\text { Generalised } \\
\text { description }\end{array}$ & $\begin{array}{c}\text { Examples of features that could be } \\
\text { assessed (drawn from flood risk } \\
\text { management) }\end{array}$ & $\begin{array}{c}\text { Example statements by author's } \\
\text { interviewees illustrative of } \\
\text { justice/belonging }\end{array}$ \\
\hline \multirow{3}{*}{ CG1 } & & $\begin{array}{ll} & \text { Availability and suitability for } \\
\text { amenity use of: }\end{array}$ & \multirow{11}{*}{$\begin{array}{l}\text { '... some dog-walkers came up } \\
\text { behind me ... and I suddenly realise } \\
\text { I'm looking at this [farmland] as a } \\
\text { floodplain asset ... and they're } \\
\text { looking at that's where they exercise } \\
\text { their dogs every day. Plus ... a nine } \\
\text { to five job as well ... grazing cattle } \\
\text { and things. [professional] } \\
\text { 'people are always asking if they can } \\
\text { walk along, or how to get down to the } \\
\text { foreshore. It's just the way it's been } \\
\text { and can't conceive of them blocking } \\
\text { off the accesses. It would have } \\
\text { changed the whole character of this } \\
\text { end of the village.'[citizen] }\end{array}$} \\
\hline & Ideally suitable & $\begin{array}{c}\text { Access to desirable adjoining } \\
\text { features (e.g. foreshore) }\end{array}$ & \\
\hline & Very inclusive & o Access along asset & \\
\hline \multirow[t]{2}{*}{ CG2 } & Suitable & $\begin{array}{ll}\text { o } & \text { Disabled access } \\
\text { o } & \text { Seating availability }\end{array}$ & \\
\hline & Inclusive & $\begin{array}{l}\text { - Views of waterscape / } \\
\text { landscape / Viewing points }\end{array}$ & \\
\hline \multirow[t]{2}{*}{ CG3 } & Acceptable & $\begin{array}{l}\text { Availability and suitability for } \\
\text { landowner use and enjoyment of }\end{array}$ & \\
\hline & $\begin{array}{l}\text { Neither inclusive or } \\
\text { exclusive }\end{array}$ & $\begin{array}{l}\text { - } \quad \text { Seatures such as the above } \\
\text { ownership of asset }\end{array}$ & \\
\hline \multirow[t]{2}{*}{ CG4 } & Unsuitable & $\begin{array}{l}\text { Degree of multiple functionality } \\
\text { afforded }\end{array}$ & \\
\hline & Exclusive & & \\
\hline \multirow[t]{2}{*}{ CG5 } & Very inappropriate & & \\
\hline & Very exclusive & & \\
\hline
\end{tabular}




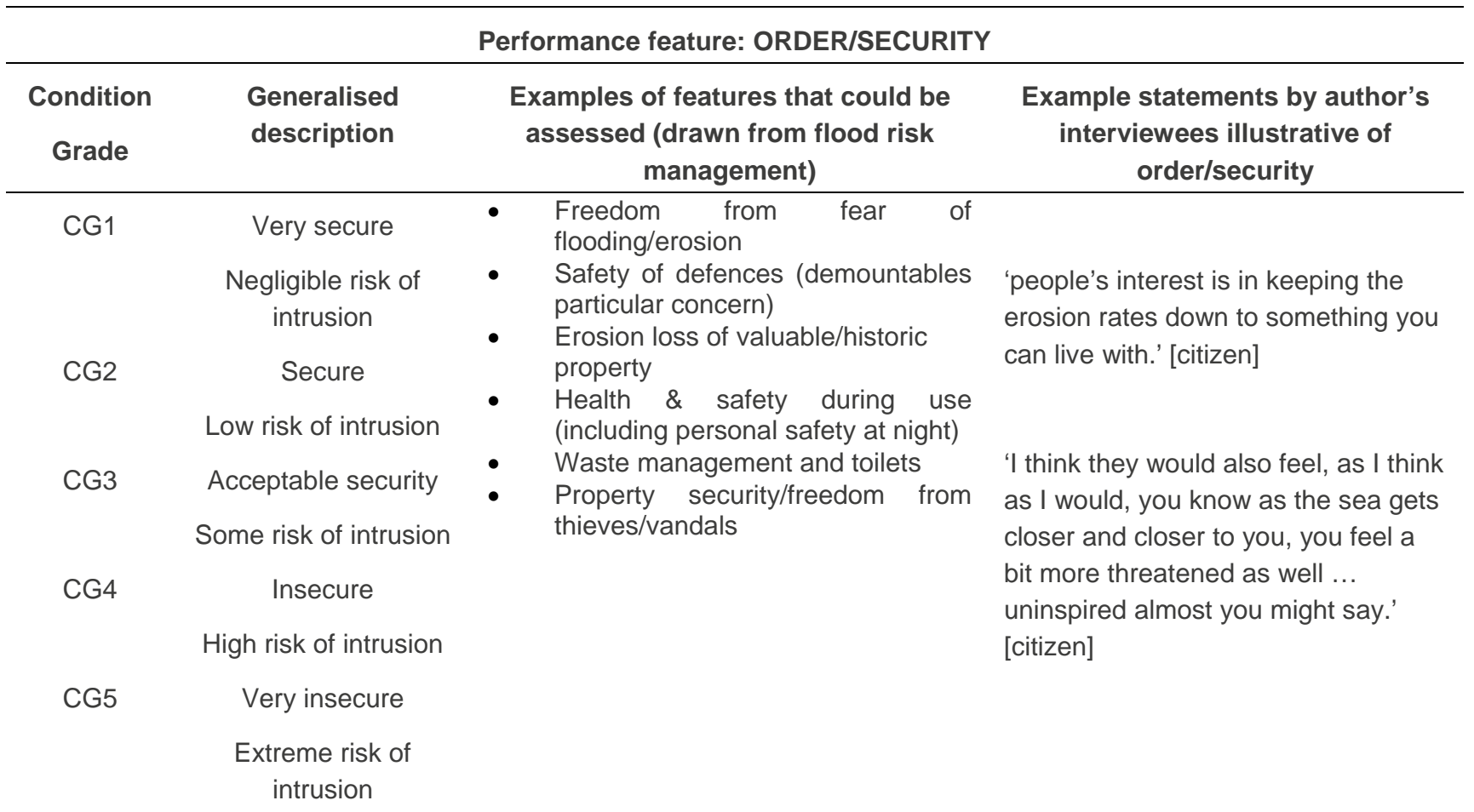

Table 5. Human dimensions of engineering assets/systems

A simplified scale also allows, as suggested in the introduction, the monitoring of changes in condition (deterioration or improvement) as part of asset management. When it comes to human factors, change is often as unwelcome as it is real and present. Many of the author's interviewees in the flood and coastal risk management field emphasised this. One professional said:

\section{'A recurring theme across the coast [is] that people don't like change; very often they tend to have false memories or idealised memories of what the coast was like and from that one day when they were six years old and it was lovely and sunny and they had an ice cream in their hand, or whatever, something similar to that.'}

The reality of course is that change happens: structures deteriorate with time, climate changes, socioeconomic factors change. All of these guarantee that both completely engineered infrastructure systems and natural resource/risk systems will also change (Hooper et al, 2009, Thorne et al, 2007).

Perceptions of such changes may vary. For example, structural deterioration is negative from the perspective of delivering order-security, but may be positive for imagination-inspiration as illustrated by the painting (Fig.

8) of deteriorated timber groynes by an artist interviewed during the course of the research. 


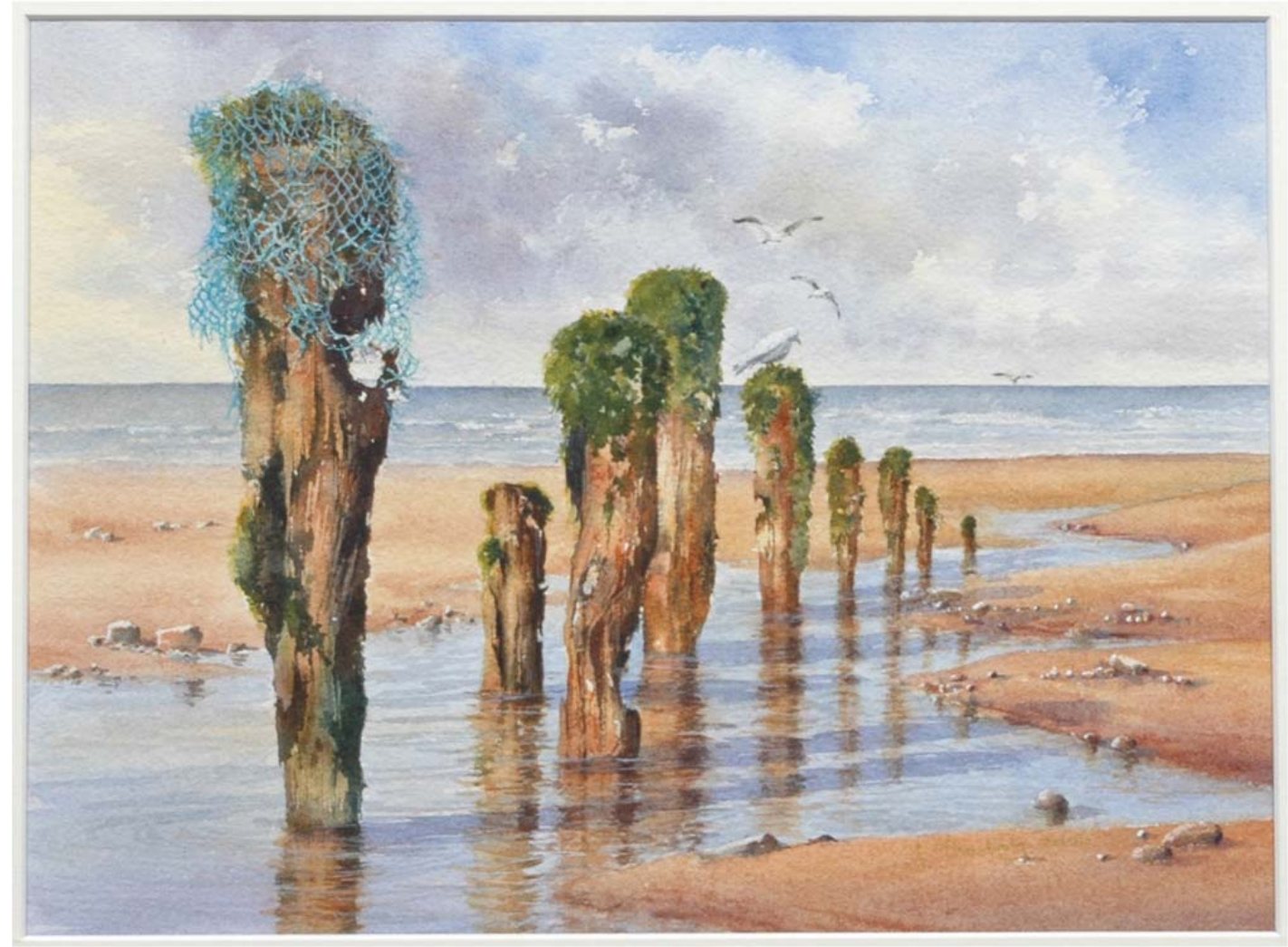

Fig. 8. 'Groynes at Spurn Point': a painting by Janet Thackaray inspired by a deteriorated structure

\subsection{Tensions in human needs and aspirations}

Some respondents (mainly flood risk management professionals) confirmed that a particular human dimension might be in tension with another one. The following example quotations from interviews with professionals illustrate the point:

'The biggest most expensive properties ... that we deal with, are all along the river Thames. People will pay extra for the view, as they see it, or pay extra for the flood risk, as I see it.'

'You might grade them differently to me, to somebody else, I think it depends very much on their interests are, what the individual person's interest is, to what they think is good and bad. But if you look at something simple like a tree across a bridge [opening], to you and I it might be "Ooh, that's reducing the capacity of the opening, it's going to cause a blockage" to perhaps a member of the general public it might be "Ooh, look, that's going to gather all sorts of litter, it's going to look awful" to perhaps someone who likes otters it might be "Oh look there's a path for the otter to take from one side of the watercourse to the other" or "Oh look, a bird's nested in it". ... So it's very much perception, so that simple tree across a bridge [opening] could ... on a scale [of] 1 being awful to 10 being good ... cover the whole range depending on perception.'

The distinctions between the three human dimensions in Table 4 allows this difference or tension, where present, to be explicitly captured, without having to compromise views of those involved. 


\subsection{Assessing within the framework}

The selected final categories of human dimensions are believed to be sufficiently generic to permit identification within them of locally specific and relevant performance features. However, to be valid the locally specific features must be developed via a participatory process able to take account of the wishes and aspirations of local community groups as well as the views of professionals. As one professional interviewed said:

‘you have to learn what other people value. It's no good going in there and thinking that you know what they'll value.'

The process of assessment is therefore envisaged to involve two distinct stages: dialogue and deliberation.

The first stage is to identify within each of the three dimensions those aspects of performance appropriate to the local place-based community. This process of dialogue (Isaacs, 1993; Gergen et al, 2004) amongst themselves and with professionals should include "seeing the whole that encompasses the parts, seeing connections and relationships, inquiring into assumptions, learning through enquiry and discourse, [and] creating shared meaning among many" (Ellinor \& Gerard, 1998).

The second stage is to agree what scoring the dimension should be given based on the collected list of performance features. Here unless the decision is to be relegated to expert-judgement, deliberation will be needed amongst the citizens and professionals, 'a conversation whereby individuals speak and listen sequentially before making a collective decision' (Austen-Smith, cited by Gambetta, 1998, 19).

A trial of this dialogue/deliberation process with one of the self-help citizen groups and invited relevant local professionals is planned as part of the ongoing research. An interesting aspect of this trial will be the emergent time and costs, given that there may be pressures to 'simplify' the process down to the expert judgment of a professional assessor.

One question which is still to be resolved is the scale at which the various human dimensions should be assessed. Early thinking suggests that a scale similar to that of a parish is probably going to dominate. (For example, Village Design Statements are used to describe the attractive characteristics of a locality that can be adopted by local planning authorities under the UK Planning and Compulsory Purchase Act (2004) as either material considerations or as Supplementary Planning Documents.)

\section{Obstacles to delivering human dimensions}

When interviewees were asked to comment on whether there had been any tensions between professionals and members of the local community over the form and management of the defences, structures and channels for the benefit of local citizens, three significant concerns emerged.

One concern inevitably related to cost. A professional commented:

'One [team] has encouraged footpaths which, I suppose I have to think, is a good idea really, and another [team] is absolutely dead against them, or has been, certainly, because of the maintenance commitment'.

The genuine underlying concern that this quotation illustrates is that if embedded human features are included there will be insufficient budget to construct or maintain engineering assets or systems. However, seeking to improve human dimensions will not necessarily add significantly to the budget and with imagination and local support, much can be achieved with little funding. It is also the case that whilst funding 
may be highly constrained, the prospect of adding socially beneficial features often opens the door to additional funding streams. Furthermore exploration of these funding sources in a multi-objective context for a scheme will promote discussion about meeting social objectives in addition to the technical requirements of a basic flood and coastal defence scheme.

A second issue that came up repeatedly with interviewees was the question of providing access to or along engineering assets. Access is desirable for people to feel they belong, but provision of access may conflict with security and safety:

'The community copper for the area ... forced his way into the debate about the width and depth and plant form of the new river, because he [was worried about]... passage over the river by thieves - there were some fairly well off people on one side of the river, and some fairly poor people on the other side of the river, and there was [already] a brisk traffic in stolen materials. So he wanted width and depth adjusted to stop criminals, he also badly wanted to stop new bridges because youths would gather underneath to sniff glue.' [director of volunteer charity]

And again

'A conscious decision [was] made ... that public access onto this [long rockfill] berm would only be provided at the upstream and the downstream end; because we didn't want the public climbing up... there's a fence ... in fact we wanted to discourage people using this access way, so we didn't put in intermediate access/egress points ... [and the pieces of rock were] obvious targets for vandals. I do like to see the good in people, but sometimes it's quite difficult.' [professional]

In such situations a balancing of risks against benefits has to be sought when establishing different human dimensions, having identified the priorities of all stakeholders involved.

A final concern of flood risk management professionals related to the lack of public awareness of the security function of defence assets and systems (e.g. that an embankment is there to deliver flood protection.) One resident involved in closing small flood gates at times of flood risk commented honestly that the flood gates had become so accepted by people that

'as long as [the gates] work when we need them to work, we don't give them any thought. They're not a consideration for anybody. I don't think, in fact the locals pass by the gates without giving them a second thought now'

Ongoing research by the author is exploring the extent to which direct involvement by local self-help groups in the monitoring and management of these assets can improve an awareness of their engineering functionality as well as improving their human dimensions.

\section{Conclusion}

The paper has established that there is a gap in the understanding of the human dimensions of structures and systems for application in engineering practice. Investigating a wide variety of literature from a number of disciplines it draws together common elements of human need with those evidenced by engineering artefacts to generate a framework for human dimensions of engineering structures and systems. Three dimensional groupings are identified: order-security, belonging-justice and imagination-inspiration. These are supported not only by the literature but also by the evidence of ethnographic work, mainly semi-structured 
interviews, in the field of flood risk management. A simple 1-5 scale is presented for each dimension. The challenges of assessing within this framework and the obstacles to actually delivering human dimensions have been discussed.

The implications of this work are that assessment of the human dimensions of structures is an appropriate and feasible endeavour, with commitment of professionals and involvement of the relevant place-based communities. Further work based on piloting is needed to establish the details of an operational protocol for use of the framework.

The benefits of adopting the approach developed in this paper as part of the management of engineering infrastructure systems, such as flood risk, include improving connection and communication between the engineering profession and the communities it serves, helping to recognise the planned and accidental benefits and dis-benefits of existing structures and systems and allowing appropriate human dimensions to be better included in the future.

\section{Acknowledgements}

This paper has been prepared as part of PhD research by the author at the University of Nottingham. The support of supervisors Dr Michael Mawdesley, Dr Susanne Seymour and Prof. Colin Thorne is much appreciated, as is the doctoral training funding received from the Engineering and Physical Sciences Research Council and the support of the author's employer, HR Wallingford.

\section{References}

Alexander, C. (2004) The nature of order: an essay on the art of building and the nature of the universe. Book 1: the phenomenon of life. Berkeley CA: Centre for Environmental Structure.

Alexander, C., Ishikawa, S., Silverstein, M., Jacobson, M., Fiksdahl-King, I. and Angel, S. (1978) A pattern language: towns, buildings, construction. Berkeley, CA: Oxford University Press Inc.

American Society of Civil Engineers (2009). Code of Ethics. Downloaded on 24 February 2009 from http://www.asce.org/files/pdf/codeofethics01222007.pdf

Baldwin, D. (1997) The concept of security. Review of International Studies, 23(1), 5-26

Bartuska, T.J. (2007) The built environment: definition and scope. In: McClure WR and Bartuska TJ (eds) The Built Environment: A Collaborative Inquiry into Design and Planning. Hoboken (NJ): John Wiley \& Sons, 3-14.

Bell, S. and Morse, S. (2003) Measuring sustainability: learning by doing. London: Earthscan Publications.

Bisset, R (1988) Developments in EIA methods. In: Wathern (ed.) Environmental Impact Assessment: theory and practice. London: Routledge, 47-61.

Blockley, D and Godfrey, P. (2000) Doing it differently: systems for rethinking construction. London: Thomas Telford.

Bryce, D. (1995) Symbolism of the Celtic cross. Red Wheel/Weiser.

Burgess, R.G. (1982) The unstructured interview as a conversation. In: Burgess (ed.) Field research: a sourcebook and field manual. London: Allen \& Unwin, 107-110 
Checkland, P. and Poulter, J. (2006) Learning for action: a short definitive account of soft systems methodology and its use for practitioners, teachers and students. Chichester: John Wiley.

Cohen, A.P. (1985) The symbolic construction of community. London: Ellis Horwood.

Cook, I. and Crang, M. (1995). Doing ethnographies (Concepts and techniques in modern geography No 58). Norwich: UEA School of Environmental Sciences.

Cook, K., Harden, R. and Levi, M. (2005) Cooperation without trust? New York: Russell Sage Foundation.

Crang, M. (2005) Analysing qualitative materials. In: Flowerdew \& Martin, (eds) Methods in human geography; a guide for students doing a research project, $2^{\text {nd }}$ edition. Harlow: Pearson Education, 218-232.

Cruickshank, I., White, P. and McConnell, K. (2005) Integrating architecture and engineering in coastal waterfront development - dealing with the challenges. Proc. Int. Conf. Coastlines, Structures and Breakwaters. London: Thomas Telford, 429-441.

Delanty, G. (2003) Community. London: Routledge.

Disabilities Discrimination Act (1995) Downloaded from http://www.opsi.gov.uk/acts/acts1995/ukpga 19950050 en 1 on 27th May 2010.

Ellinor, L. and Gerard, G., 1998. "Dialogue: rediscover the transforming power of conversation." New York: John Wiley \& Sons.

Environment Agency (2010) Flood and Coastal Erosion Risk Management appraisal guidance - Supporting Document for the Appraisal Summary Table. Bristol, Environment Agency, March. Downloaded from http://publications.environment-agency.gov.uk/pdf/GEHO0310BSDD-e-e.pdf on 27th May 2010.

Fielding. N. and Thomas, H. (2001) Qualitative interviewing. In: Gilbert, (ed.) Researching social life second edition. London: Sage, 123-144.

Flikweert, J. and Simm, J. (2008) Improving performance targets for flood defence assets. J Flood Risk Management, 1(4), 201-212.

Foresight Flood \& Coastal Defence Project (2004) Future Flooding volume 2: Managing future risks http://www.bis.gov.uk/foresight/our-work/projects/published-projects/flood-and-coastal-defence/projectoutputs/volume-2 (downloaded on 15 November 2010)

Gambetta, D. (1998) Claro!: an essay on discursive machismo. In: Elster (ed.) Deliberative democracy. Cambridge: Cambridge University Press, 19-43

Gergen, K. Gergen, M. and Barrett, F. (2004) Dialogue: life and death of the organisation. In: Grant, Hardy, Oswick and Putnam (eds) The Sage handbook of organisational discourse, London: Sage, . 39-59.

Gorringe, T. (2002) A theology of the built environment: justice, empowerment, redemption. Cambridge: Cambridge University Press.

Gouldby, B. and Samuels, P. (2005) FLOODsite language of risk: project definitions. Downloaded on 22 August 2010 from

http://www.floodsite.net/html/partner area/project docs/FLOODsite Language of Risk v4 0 P1.pdf

Gouldby, B., Sayers, P., Mulet-Marti, J., Hassan, M. and Benwell, D. (2008) A methodology for regionalscale flood risk assessment. Proceedings of the Institution of Civil Engineers - Water Management, 161(3), 169-182, June. 
Gwilt, J. (2007) English translation of Text of Marcus Vitruvius Pollio's De Architectura, Book I downloaded on 07/06/2007 from http://penelope.uchicago.edu/ Thayer/E/Roman/Texts/Vitruvius/1*.html

Hall, J., Dawson, R., Sayers P., Rosu, C., Chatterton, J. and Deakin, R. (2003) A methodology for nationalscale flood risk assessment. Proceedings of the Institution of Civil Engineers-Water and Maritime Engineering, 156 (3), 235-247.

Hall, J., Dawson, R., Manning, N., Walkden, M., Dickson, M. and Sayers, P. (2006) Managing changing risks to infrastructure systems. Proceedings of the Institution of Civil Engineers-Civil Engineering, 159, 21-27.

Hooper, R., Armitage, R., Gallagher, A. and Osorio, T. (2009) Whole-life infrastructure asset management: good practice guide for civil infrastructure. London: Construction Industry Research and Information Association, Report C677, 73-76.

Institution of Civil Engineers (2004). Code of professional conduct. http://www.ice.org.uk/downloads/CODE\%200F\%20PROFESSIONAL\%20CONDUCT.doc (Downloaded on $4^{\text {th }}$ May 2009).

International Association of Impact Assessment (2003) Social impact assessment - international principles. Tasmania, International Association of Impact Assessment, Special Publication No 2. Downloaded from http://www.iaia.org/publicdocuments/special-publications/SP2.pdf on 27th May 2010.

Inwood, M. (1997) Heidegger - a very short introduction. Oxford: Oxford University Press.

Isaacs, W. (1993) Taking flight: dialogue, collective thinking and organizational learning, Organizational Dynamics, 22, 24-39

Kesby, M., Kindon, S. and Pain, R. (2005) ‘Participatory' approaches and diagramming techniques. In: Flowerdew \& Martin (eds) Methods in human geography; a guide for students doing a research project, $2^{\text {nd }}$ edition. Harlow: Pearson Education, 144-166.

Liepins, R. (2000) New energies for an old idea: reworking approaches to 'community' in contemporary rural studies. Journal of Rural Studies, 16, 23-35.

Longhurst, R. (2003) Semi-structured interviews and focus groups. In: Clifford \& Valentine, (eds) Key methods in geography. London: Sage, 117-132.

Maslow, A. (1943) A theory of human motivation. Psychological Review, 50, 370-396.

Maslow, A. (1954) Motivation and personality. New York: Harper.

McMillan, D. and Chavis, D. (1986) Sense of community: a definition and theory. Journal of community psychology, 14, 6-23.

Miller, D. (1999) Principles of social justice. Cambridge, MA: Harvard University Press.

Neher. A. (1991) Maslow's theory of motivation: a critique. Journal of Humanistic Philosophy, 1991, 31(3), 89-112.

Nussbaum, M.C. (2000) Women and human development - the capabilities approach. Cambridge: Cambridge University Press.

Nussbaum, M.C. (2006) Capabilities as fundamental entitlements: Sen and social justice. In: Kaufman (ed) Capabilities equality - basic issues and problems. New York: Routledge, 44-70. 
Office of Science and Technology (2004) Foresight Future Flooding Scientific Summary: Volume II Managing future risks. London: Office of Science and Technology. http://www.foresight.gov.uk/OurWork/CompletedProjects/Flood/Docs/Volume2/Scientific Summary Volume 2.asp (Downloaded on 28 May 2010)

Oliver, A. (2007) New definition of civil engineering. New Civil Engineer 31 October. http://www.nce.co.uk/new-definition-for-civil-engineering/212786.article (Downloaded on 17 May 2010)

Parkin, S, Sommer, F. and Uren, S. (2003) Sustainable development: understanding the concept and practical challenge. Proc. Instn. Civ. Engrs., Engineering Sustainability, 156 (ES1), 19-26.

Planning and Compulsory Purchase Act (2004). http://www.legislation.gov.uk/ukpga/2004/5/contents (Downloaded on 15th November 2010)

Rawls, J. (1971) A theory of justice. Cambridge, MA: Harvard University Press.

Rawls, J. (2001) Justice as fairness: a restatement. Cambridge, MA: Harvard University Press.

Robeyns, I, and Brighouse, H. (2010) Introduction: social primary goods and capabilities as metrics of justice. In Brighouse and Robeyns (eds) Measuring justice: primary goods and capabilities. Cambridge: Cambridge University Press, 1-13.

Roth, L. (2007) Understanding architecture: its elements, history and meaning. Boulder CO: Westview Press. Sarason, S.B. (1974) The psychological sense of community - perspectives for community psychology. San Francisco: Jossey Bass.

Sen, Amartya K. (1985). Commodities and capabilities. Oxford: Oxford University Press.

Sen, A. (1993) Capability and well-being. In: Nussbaum and Sen (eds) The quality of life. Oxford, Clarendon Press.

Silf, M. (2001) Sacred spaces: stations on a Celtic way. Oxford: Lion Publishing.

Simm, J., Wallis, M., Sayers, P., Gouldby, B., Buijs, F., Flikweert, J-J and Hamer, B. (2006) Developing a performance-based management system for flood and coastal defence assets. Proceedings $41^{\text {st }}$ Defra Flood \& Coastal Management Conference. York. London, Defra, Paper 09.10.

Simm, J., Gouldby, B, Sayers, P., Flikweert, J, Wersching, S and Bramley, M. (2008) Representing fragility of flood and coastal defences: getting into the detail. Proc. Eur, Conf. on Flood Risk Management: Research into Practice (FLOODrisk 2008). London: Taylor \& Francis, 621-631.

Simm, J.D. and Thorne, C.R. (2007). Response scoring, ranking, uncertainty and sustainability. In Thorne, Evans \& Penning-Rowsell (eds) Future flooding and coastal erosion risks. London: Thomas Telford, 414432.

Thorne, Evans \& Penning-Rowsell (eds) (2007) Future flooding and coastal erosion risks. London: Thomas Telford, 414-432.

Tunstall, S.M., Johnson, C.L. and Penning-Rowsell, E.P. (2010) Flood Hazard Management in England and Wales: From Land Drainage to Flood Risk Management. Proc. World Congress on Natural Disaster Management. http://www.fhrc.mdx.ac.uk/resources/docs pdfs/India\%20paper\%20final\%20version.pdf (downloaded on 28 May 2010) 
Valentine, G. (2005) Tell me about ...: using interviews as a research methodology. In: Flowerdew \& Martin (eds) Methods in human geography; a guide for students doing a research project, $2^{\text {nd }}$ edition. Harlow: Pearson Education, 110-127.

Vanclay, F. (2002) Conceptualising social impacts. Environmental Impact Assessment Review, 22, 183 211.

Warburton, D. (1998) A passionate dialogue: community and sustainable development. In: Warburton, D. (ed.) Community and sustainable development; participation in the future. London: Earthscan, 1-39.

Wathern, P. (1988) An introductory guide to EIA. In: Wathern (ed.) Environmental Impact Assessment: theory and practice. London: Routledge, 3-30.

Wolfers, A (1952) "National Security" as an ambiguous symbol. Political Science Quarterly, 67 (4), 481-502. 